\title{
Indoor air quality of a museum in a subtropical climate: The Oscar Niemeyer museum in Curitiba, Brazil
}

\author{
Ricardo H.M. Godoi a,*, Barbara H.B. Carneiro ${ }^{\text {b}}$, Sarah L. Paralovo ${ }^{\text {a }}$, Vania P. Campos ${ }^{\text {c }}$, Tania M. Tavares ${ }^{\text {c, }}$ \\ Heitor Evangelista ${ }^{\mathrm{d}}$, Rene Van Grieken ${ }^{\mathrm{e}}$, Ana F.L. Godoi ${ }^{\mathrm{a}}$ \\ a Federal University of Paraná, Environmental Engineering Department, Curitiba, PR, Brazil \\ b University of Positivo, Curitiba, Brazil \\ ${ }^{\mathrm{c}}$ Institute of Chemistry, Federal University of Bahia, Salvador, BA, Brazil \\ ' LARAMG/Department of Biophysics and Biometry, Rio de Janeiro State University, Rio de Janeiro, RJ, Brazil \\ e Department of Chemistry, University of Antwerp, Universiteitsplein 1, B-2610 Antwerp, Belgium
}

\section{H I G H L I G H T S}

- Analysis of compounds that participate in reactions that damage artwork surfaces.

- Aim: assess damage to artwork caused by pollution in hot and humid environments.

- MON has satisfactory air quality when compared to other international museums.

- The situation could improve by using higher efficiency filters in the HVAC system.

\section{A R T I C L E I N F O}

\section{Article history:}

Received 20 December 2012

Received in revised form 13 February 2013

Accepted 22 February 2013

Available online 22 March 2013

\section{Keywords:}

Air quality in museums

Conservation

Indoor air pollution

Gases

Particulate matter

Tropical museum

\begin{abstract}
A B S T R A C T
The assessment of damage to indoor cultural heritage, in particular by pollutants, is nowadays a major and growing concern for curators and conservators. Nevertheless, although many museums have been widely investigated in Europe, the effects of particulate matter and gaseous pollutants in museums under tropical and subtropical climates and with different economic realities are still unclear. An important portion of the world's cultural heritage is currently in tropical countries where both human and financial resources for preserving museum collections are limited. Hence, our aim is to assess the damage that can be caused to the artwork by pollution in hot and humid environments, where air quality and microclimatic condition differences can cause deterioration. As a case study, particulate matter as well as gases were collected at the Oscar Niemeyer Museum (MON) in Curitiba, Brazil, where large modern and contemporary works of art are displayed.

$\mathrm{NO}_{2}, \mathrm{SO}_{2}, \mathrm{O}_{3}$, Acetic Acid, Formic Acids and BTEX, in the ambient air, were sampled by means of passive diffusive sampling and their concentrations were determined by IC or GC-MS.

The particulate matter was collected in bulk form and analyzed with the use of energy dispersive X-ray fluorescence and aethalometer. The chemical compositions of individual particles were quantitatively elucidated, including low-Z components like $\mathrm{C}, \mathrm{N}$ and $\mathrm{O}$, as well as higher-Z elements, using automated electron probe microanalysis. The gaseous and particulate matter levels were then compared with the concentrations obtained for the same pollutants in other museums, located in places with different climates, and with some reference values provided by international cultural heritage conservation centers. Results are interpreted separately and as a whole with the specific aim of identifying compounds that could contribute to the chemical reactions taking place on the surfaces of artifacts and which could potentially cause irreversible damage to the artworks.
\end{abstract}

(c) 2013 Elsevier B.V. All rights reserved.

\section{Introduction}

The global warming threats can intensify the synergisms between climate and urban air pollution, especially in large parts of South America, where the high humidity and air pollution are a reality. An important

\footnotetext{
* Corresponding author. Tel.: +55 4188569504.

E-mail address: rhmgodoi@ufpr.br (R.H.M. Godoi).
}

portion of the world's cultural heritage resides in tropical and subtropical regions, where both human and financial resources for preserving museum collections are limited. Although many museums have been widely investigated in Europe and the United States (Camuffo et al., 1999, 2001; Godoi et al., 2006a, 2008; Kontozova-Deutsch et al., 2008, 2011a, b; Ionescu et al., 2012), studies of the presence and effects of particulate matter and gaseous pollutants in museums of developing countries with non-temperate climates and with different economic realities are still 
lacking. Besides these "longitudinal" threats, physical, biological and chemical factors as pollution and its synergism should be considered in the sense of preservation.

The conservation of typical collections such as woods, papers, leathers, among others, is directly related to the indoor environment of the museums, and it is especially sensitive to high levels of temperature and relative humidity (Brimblecombe et al., 1999; Camuffo et al., 1999; Bencs et al., 2007; Cappitelli et al., 2009; Kontozova-Deutsch et al., 2011a,b; Lankester and Brimblecombe, 2012). When the relative humidity ( $\mathrm{RH})$ is high, chemical reactions may increase, just as when temperature is elevated. Many chemical reactions require water; so at high $\mathrm{RH}$, chemical deterioration can proceed more rapidly. High humidity also supports biological activity; for instance, mold growth is more likely as $\mathrm{RH}$ rises above $65 \%$, as well as the insect activity (Lefevre, 1974).

For artwork, the best environment is a climatically stable one, where there is only slight variation in temperature and $\mathrm{RH}$ and where the air pollution concentration is sufficiently low. The synergism between pollutants, temperature and/or humidity can swell/shrink objects, and the results are destructive (Brimblecombe et al., 1999; Camuffo et al., 1999). The effect is noteworthy because paint might crack on a canvas or pop off from a painted object, wooden veneers might peel away, glued joints on wooden furniture might fail, and wooden objects might be permanently warped (Bratasz et al., 2007).

Looking at the air pollution indoors, where the most vulnerable artworks are stored, it is important to focus on components that have a potential deterioration effect such as some gases (e.g., $\mathrm{NO}_{2}$, $\mathrm{SO}_{2}$, and $\mathrm{O}_{3}$ ), particulate matter $(\mathrm{PM})$ including black carbon $(\mathrm{BC})$ (Kontozova-Deutsch et al., 2008). More recently, organic acids as acetic and formic acids (HAc and HFor), as well as volatile organic compounds, like benzene, toluene, ethylbenzene and xylenes (BTEX), have also been considered due to their damage potential (Schieweck et al., 2005; Godoi et al., 2008). These species are also important facing the manifold sources of organic and inorganic pollutants in the indoor environment of museums.

Therefore, this research was conducted to fill this gap in a subtropical climate, by first dealing with the characterization of the indoor air quality of the Oscar Niemeyer Museum (MON) in Curitiba, south of Brazil. Although some specific pollutants have been measured in a few Brazilian museums (Grosjean et al., 1990; Druzik et al., 1990; Costa, 2003; Cavicchioli et al., 2012), to the authors' knowledge, this is the first time that a detailed survey of gases and aerosol pollution has been done systematically in a Brazilian museum.

\section{Material and methods}

\subsection{Measurement site}

The MON in Curitiba, Brazil, is a modern concrete structure divided essentially in two buildings. The main building is a regular construction, semi-open, adapted to house the art collections in ten exhibit rooms. The modern area of the MON has one tower called "The Eye", designed by the famous architect Oscar Niemeyer, in which is located the museum's major exhibit room. An underground tunnel connects both structures. Almost all parts of the museum are equipped with heating, ventilation and air conditioning systems (HVAC). Besides its own collection of about 2000 pieces of modern and contemporary art, the MON receives art expositions from others Brazilians states, as well as from different parts of the world. Fig. 1 shows the façade of the MON building.

\subsection{Sampling and instrumentation}

The sampling was carried out at MON in two periods of one week During the first week, from 30 July to 6 August 2007, the exhibition room of "The Eye" was monitored. This period is in the austral winter when pollutants tend to be mostly concentrated in the atmospheric boundary layer, therefore a critical period for the city air quality. During this week, samples for bulk and individual particle analysis, BC and gases such as $\mathrm{SO}_{2}, \mathrm{NO}_{2}, \mathrm{O}_{3}$, HAc, HFor and BTEX were collected. During the second week, from 20 to 27 August 2007, exhibit rooms from the main building were monitored. During this week, samples of BC and gaseous pollutants such as HAc, HFor and BTEX were collected (IAP, 2008).

The HVAC system is operational throughout the building. The main thermohygrometric parameters analyzed (day and night) were air temperature ( $\mathrm{T}$ ) and RH measured with automatic data loggers.

Aerosol particles for bulk analysis were collected on Nuclepore membranes using a stacked filter unit, with $24 \mathrm{~h}$ sampling time and a flow rate of $35 \mathrm{~L} \mathrm{~min}^{-1}$. Information concerning the bulk elemental concentration is provided by energy-dispersive X-ray fluorescence (EDXRF). The measurements of total PM were performed on an Epsilon-5 (PANalytical, Almelo, The Netherlands) high-energy polarized-beam (HE-P) EDXRF instrument having a three-dimensional polarizing geometry with 13 secondary targets $\left(\mathrm{W}, \mathrm{CeO}_{2}, \mathrm{CsI}, \mathrm{Ag}, \mathrm{Mo}\right.$, $\left.\mathrm{Zr}, \mathrm{KBr}, \mathrm{Ge}, \mathrm{Co}, \mathrm{Fe}, \mathrm{Ti}, \mathrm{CaF}_{2}, \mathrm{Al}\right)$ and two Barkla scatter targets $\left(\mathrm{B}_{4} \mathrm{C}\right.$ and $\mathrm{Al}_{2} \mathrm{O}_{3}$ ). The $\mathrm{X}$-ray characteristic radiation was detected by a Ge detector (PAN 32) with a full-width at half-maximum (FWHM) resolution of $165 \mathrm{eV}$, performing non-destructive quantitative analysis of elements, starting from Al.

Microanalysis is a very useful technique to identify the simultaneous presence of particular elements in an individual particle, which allows a better discrimination between specific particle types. In the present research, an electron probe microanalysis method, called low-Z EPMA, is applied to characterize quantitatively the composition of individual particles, including low-Z components like $\mathrm{C}, \mathrm{N}$ and $\mathrm{O}$, as well as higher-Z elements using a common EPMA unit (Godoi et al., 2004, 2006a,b; Avigo et al., 2008). For EPMA, aerosol particles were sampled on $\mathrm{Ag}$ foil using two stages of a May cascade impactor, with aerodynamic diameters ranging from 0.5 to $2.0 \mu \mathrm{m}$ and from 2.0 to $8.0 \mu \mathrm{m}$ for stages 6-4 and 4-2, respectively, at a $20 \mathrm{~L} / \mathrm{min}$ sampling flow to separate primarily the size fractions of interest. Low-Z EPMA was performed on a JEOL (Tokyo, Japan) 733 EPMA unit equipped with an Oxford detector with an atmospheric ultra-thin window of $0.2 \mu \mathrm{m}$. An accelerating voltage of $10 \mathrm{kV}$, a beam current of $1.0 \mathrm{nA}$ and a measuring time of $20 \mathrm{~s}$ were used. In order to avoid additional absorption and spectral interference, no conductive coating was applied on the samples. It was possible to cool the sample stage to liquid-nitrogen temperature (about $196{ }^{\circ} \mathrm{C}$ ), which mitigated beam damage to the sample. Computercontrolled X-ray data acquisition for individual particles was carried out automatically in point analysis mode, i.e. the electron beam was focused on the center of each particle, and X-rays were acquired while

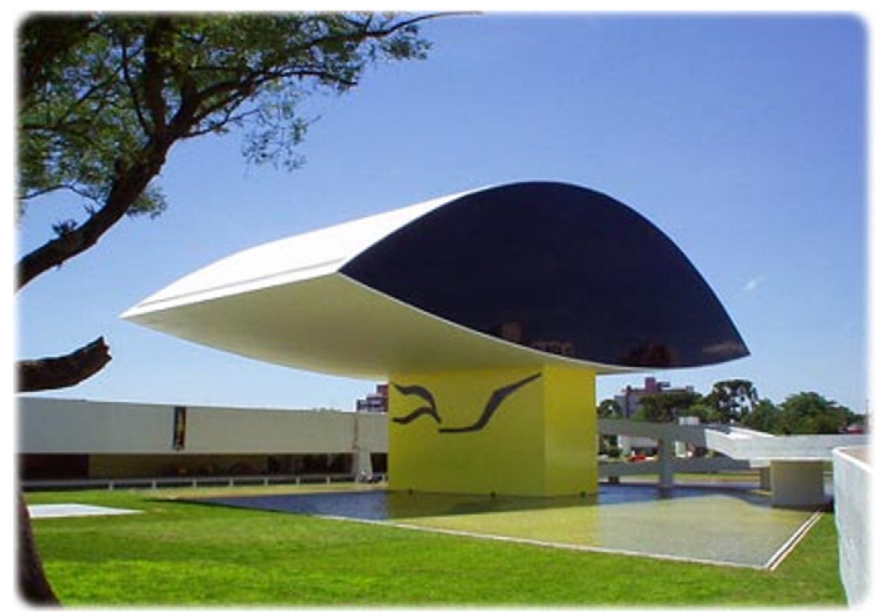

Fig. 1. Façade of the Oscar Niemeyer Museum (MON), in Curitiba, Brazil. 
the beam remained fixed on this single spot. The data from these estimated X-rays were used as input parameters for the quantification procedure. Approximately 400 particles were measured in each stage, so in this way almost 800 individual aerosol particles were analyzed in one sample set; in total, the complete analysis included more than 4000 particles. Carbonaceous particles can be separated in three different groups of species: biogenic, soot and organic particles (Godoi et al., 2004). Particles are identified to be biogenic when the concentrations of $\mathrm{C}$ and $\mathrm{O}$ are similar and they also contain some N, $\mathrm{P}$ and/or $\mathrm{S}$ contents ( $>10 \% \mathrm{wt}$ ), which are characteristic elements for biogenic species. When $\mathrm{C}$ content is about three times higher than the $\mathrm{O}$ content (or more), the particle is identified as soot. Particles are considered to be organic when they do not match the criteria above for biogenic or soot particles. Organic particles can act as a medium for the adsorption and incorporation of damaging gases, such as $\mathrm{SO}_{2}$, and allow them to participate in a possible weathering process. Particles were identified as $\mathrm{CaCO}_{3}$ when the stoichiometry ratio of $\mathrm{Ca}, \mathrm{O}$ and $\mathrm{C}$ was kept $>70 \% \mathrm{wt}$; similarly, particles with more than $70 \%$ wt of $\mathrm{Ca}, \mathrm{O}$ and $\mathrm{S}$ were identified as $\mathrm{CaSO}_{4}$. Particles with high sulfur content, more than $70 \% \mathrm{wt}$, were identified as S-rich. If these particles have $10-15 \%$ of $\mathrm{Cl}$, the particle was classified as S-Cl-rich. Particles that contain more than $50 \%$ wt of $\mathrm{Cl}$ are considered as $\mathrm{Cl}$-rich particles. Fe-containing particles are also encountered and two different types of Fe-containing particles were identified: $\mathrm{Fe}_{2} \mathrm{O}_{3}$ and $\mathrm{Fe}$ metal. Most of Fe metal particles contain $70-80 \%$ of $\mathrm{Fe}$ with some $\mathrm{C}$ and $\mathrm{O}$, due to surface oxidation. In this work, all Fe-containing particles are denoted by "FeO". Many distinctive particle types were identified, according to their chemical composition. Since this technique can determine the chemical species at least semiquantitatively, some individual particles were identified as internal mixture particles, which are composed of two or more chemical species. However, it is somewhat difficult to clearly determine if particles are composed of only one chemical species or more, especially for aluminosilicate species. These types of particles were identified as mixed.

The gaseous compounds BTEX, $\mathrm{SO}_{2}, \mathrm{NO}_{2}, \mathrm{HAc}$, and HFor were sampled on two types of cartridges in parallel and continuously ( $24 \mathrm{~h}$ for seven consecutive days) by means of radiello ${ }^{\circledR}$ diffusive passive samplers from Fondazione Salvatore Maugeri (Padova, Italy). The adsorbing cartridges for BTEX consist of $60 \mathrm{~mm}$ length stainless steel net cylinders, with 100 mesh grid opening and $5.8 \mathrm{~mm}$ diameter, packed with $530 \pm 30 \mathrm{mg}$ of activated charcoal with a particle size of 35-50 mesh (Cocheo et al., 1996). For $\mathrm{O}_{3}$, the samplers are chemiadsorbing cartridges, consisting of a microporous polyethylene cylinder $(5.8 \mathrm{~mm}$ diameter, $60 \mathrm{~mm}$ height), impregnated with triethanolamine (Campos et al., 2010).

After desorption with carbon disulfide $\left(\mathrm{CS}_{2}\right)$, BTEX were analyzed with a gas chromatograph (Varian GC-MS, Walnut Creek, CA, USA). The analytical methodology can be found elsewhere (Godoi et al., 2009). $\mathrm{SO}_{2}, \mathrm{NO}_{2}, \mathrm{HAc}$, and HFor were determined by means of ion chromatography (dual column Dionex DX-120), with conditions previously established (Stranger et al., 2009). Ozone was sampled using homemade analyzed by ion chromatography as stated by Campos et al. (2010). BC was monitored by an aethalometer (Magee Scientific, model Ae-10) (Hansen and Schnell, 1991; IPCC, 2001). Table 1 describes the locations, the type of analysis done and the date/duration of the samplings performed.

\section{Results and discussions}

Comparing the mean temperature and humidity values obtained at MON to values obtained by studies in other museums, one may observe that the mean temperatures ("Eye" building: $18^{\circ} \mathrm{C}$, Room $1: 18^{\circ} \mathrm{C}$, Room 2: $18{ }^{\circ} \mathrm{C}$, Room 3: $19{ }^{\circ} \mathrm{C}$ ) are similar to the ones obtained in sampling campaigns performed in winter time in different museums, as the Correr Museum (CM), Italy, with a mean temperature of $15.3^{\circ} \mathrm{C}$ (Camuffo et al., 1999), the Kunsthistorisches Museum (KHM), Austria, $19{ }^{\circ} \mathrm{C}$ (Camuffo et al., 2001), the Sainsbury Centre for Visual Arts (SCVA), England, $20{ }^{\circ} \mathrm{C}$ (Brimblecombe et al., 1999) and of the Royal Museum of Fine
Arts (RMFA), Belgium, with a mean temperature of $21{ }^{\circ} \mathrm{C}$ (Gysels et al., 2004). However, when comparing the mean RH rates (MON: "Eye": $68 \%$, Room 1: $62 \%$, Room 2: $62 \%$, Room 3: $59 \%$ ) to the ones obtained in the European museums (CM: 41\%, KHM: 60\%, SCVA: 45\%, RMFA: 40\%), one notices that the values in the Brazilian museum are relatively high. The higher $\mathrm{RH}$ rates are characteristic for tropical and subtropical climates. The microclimatic homogeneity cannot be discussed in this work because the thermo-hygrometric equipment used does not have high resolution and fast response.

\subsection{Particulate matter}

Although we do not have a time series to describe at high resolution the diurnal variability of PM, it is reasonable to propose that the indoor concentrations of total PM are expected to depend on aerosol transport from outdoors and also on the transit of people in and into the indoor environment.

The EDXRF results obtained inside and outside of the MON are presented in Table 2. The accuracy of the applied EDXRF method and of the obtained calibration curves can be found elsewhere (Avigo et al., 2008).

No elements were detected at concentrations higher than $100 \mathrm{ng} \mathrm{m}^{-3}$. Intermediate concentrations ranging from 100 to $10 \mathrm{ng} \mathrm{m}^{-3}$ were identified for $\mathrm{S}, \mathrm{Cl}$ and $\mathrm{K}$, and $\mathrm{Ca}$, Fe and $\mathrm{Zn}$ were detected at concentrations below $10 \mathrm{ng} \mathrm{m}^{-3}$.

One of the main anthropogenic sources of some of the pollutants mentioned above is vehicle traffic, whereby $\mathrm{Cr}$, Ni, $\mathrm{Zn}$ and $\mathrm{Fe}$ are normally emitted by vehicle exhaust, $\mathrm{Cr}$, Fe and $\mathrm{Zn}$ originate from brake wear and tear, and $\mathrm{Fe}$ and $\mathrm{Zn}$ originate from the wearing of tires (Yi et al., 2001; Hildemann et al., 1991).

The high S-abundance in urban air particles could be attributed to secondary reactions on anthropogenic emissions of $\mathrm{SO}_{2}$ (Wolf and Hidy, 1997). The particulate $\mathrm{S}-, \mathrm{Cl}$ - and Si-concentrations were comparable to the findings of Gysels et al. (2004) and co-workers who studied the Royal Museum of Fine Arts in Antwerp, Belgium. However, in the Correr Museum in Venice, Sainsbury Centre for Visual Arts, Norwich and Kunsthistorisches Museum, Vienna, higher concentrations of those elements were observed (Camuffo et al., 2001).

Element depositions on glass or metals can result in the formation of complex salts (patinas and mineral crust) enhancing the corrosion process. Frequently, these salts increase the absorption of water and gases, facilitating the continuity of degradation process, as in the case of the hygroscopic sulfate particles. In addition, these newly formed minerals on the glass can lead to changes in the optical qualities of the glass (opacification and partial discoloration). For instance, it is well known to glass technologists that Fe, Mn as well as Sb can act as a decolorizing

Table 1

Sampling description.

\begin{tabular}{|c|c|c|c|c|}
\hline Date & $\begin{array}{l}\text { Sampling } \\
\text { site }\end{array}$ & Description & $\begin{array}{l}\text { Type of } \\
\text { analysis }\end{array}$ & $\begin{array}{l}\text { Sampling } \\
\text { period }\end{array}$ \\
\hline \multirow{9}{*}{$\begin{array}{c}30 / 07 \text { to } \\
06 / 08\end{array}$} & \multirow[t]{4}{*}{1} & \multirow[t]{4}{*}{ "Eye" building (HVAC system) } & Gases & 7 days \\
\hline & & & PM (bulk) & 7 days \\
\hline & & & SPA (EPMA) & 3 days \\
\hline & & & $\mathrm{BC}$ & $11 / 2 \mathrm{~h} /$ day \\
\hline & 2 & “Eye" building (HVAC system) & Gases & 7 days \\
\hline & 3 & $\begin{array}{l}\text { 2nd floor of "eye" building } \\
\text { (naturally ventilated) }\end{array}$ & Gases & 7 days \\
\hline & \multirow[t]{3}{*}{4} & & Gases & 7 days \\
\hline & & Outside & PM (bulk) & 7 days \\
\hline & & & SPA (EPMA) & \\
\hline \multirow[t]{4}{*}{$\begin{array}{c}20 / 08 \text { to } \\
27 / 08\end{array}$} & $5,6,7$ & $\begin{array}{l}\text { Room } 1 \text { - main building } \\
\text { (HVAC system) }\end{array}$ & Gases & 7 days \\
\hline & $8,9,10$ & $\begin{array}{l}\text { Room } 2 \text { - main building } \\
\text { (HVAC system) }\end{array}$ & Gases & 7 days \\
\hline & 11,12 & $\begin{array}{l}\text { Room } 3 \text { - main building } \\
\text { (HVAC system) }\end{array}$ & Gases & 7 days \\
\hline & 13 & Corridor (naturally ventilated) & $\mathrm{BC}$ & $11 / 2 \mathrm{~h} /$ day \\
\hline
\end{tabular}


Table 2

Results of the EDXRF bulk analysis ( $\mathrm{ng} \mathrm{m}^{-3}$ ) of total PM inside and outside of "The Eye" tower - MON - first week sampling (DL: Detection Limit).

\begin{tabular}{|c|c|c|c|c|c|c|c|c|c|c|c|}
\hline \multicolumn{12}{|c|}{ Elements $\left(\mathrm{ng} \mathrm{m}^{-3}\right.$ ) } \\
\hline Sampling date & sampling place & $\mathrm{Al}$ & $\mathrm{Si}$ & $\mathrm{S}$ & $\mathrm{Cl}$ & $\mathrm{K}$ & $\mathrm{Ca}$ & $\mathrm{Ti}$ & $\mathrm{Fe}$ & $\mathrm{Zn}$ & $\mathrm{Pb}$ \\
\hline \multirow[t]{2}{*}{$31 / 07$} & Inside "Eye” Tower & $<\mathrm{DL}$ & $<\mathrm{DL}$ & $29 \pm 5$ & $10 \pm 2$ & $14 \pm 1$ & $5 \pm 1$ & $<\mathrm{DL}$ & $<\mathrm{DL}$ & $<\mathrm{DL}$ & $<\mathrm{DL}$ \\
\hline & Outside & $<\mathrm{DL}$ & $24 \pm 4$ & $49 \pm 7$ & $35 \pm 2$ & $32 \pm 1$ & $22 \pm 1$ & $2 \pm 1$ & $22 \pm 2$ & $<\mathrm{DL}$ & $<\mathrm{DL}$ \\
\hline \multirow[t]{2}{*}{$01 / 08$} & Inside "Eye" Tower & $<\mathrm{DL}$ & $<\mathrm{DL}$ & $50 \pm 5$ & $12 \pm 2$ & $61 \pm 1$ & $6 \pm 1$ & $<\overline{\mathrm{DL}}$ & $<\mathrm{DL}$ & $2 \pm 2$ & $<\mathrm{DL}$ \\
\hline & Outside & $115 \pm 4$ & $167 \pm 3$ & $149 \pm 6$ & $48 \pm 2$ & $244 \pm 1$ & $214 \pm 1$ & $21 \pm 1$ & $206 \pm 2$ & $7 \pm 3$ & $<\mathrm{DL}$ \\
\hline \multirow[t]{2}{*}{$02 / 08$} & Inside "Eye" Tower & $<\mathrm{DL}$ & $<\mathrm{DL}$ & $72 \pm 5$ & $10 \pm 2$ & $122 \pm 1$ & $10 \pm 1$ & $<\mathrm{DL}$ & $7 \pm 1$ & $3 \pm 2$ & $<\mathrm{DL}$ \\
\hline & Outside & $55 \pm 4$ & $100 \pm 4$ & $113 \pm 7$ & $56 \pm 2$ & $154 \pm 1$ & $211 \pm 1$ & $12 \pm 1$ & $124 \pm 2$ & $7 \pm 3$ & $<\mathrm{DL}$ \\
\hline 03/08 & Inside "Eye" Tower & $33 \pm 3$ & $53 \pm 2$ & $57 \pm 4$ & $8 \pm 1$ & $37 \pm 1$ & $69 \pm 1$ & $4 \pm 1$ & $40 \pm 1$ & $3 \pm 2$ & $<\mathrm{DL}$ \\
\hline \multirow[t]{2}{*}{$04 / 08$} & Outside & $<\mathrm{DL}$ & $<\mathrm{DL}$ & $88 \pm 9$ & $24 \pm 3$ & $151 \pm 1$ & $17 \pm 1$ & $<\mathrm{DL}$ & $11 \pm 2$ & $5 \pm 4$ & $<\mathrm{DL}$ \\
\hline & Inside "Eye" Tower & $47 \pm 3$ & $67 \pm 2$ & $86 \pm 4$ & $30 \pm 1$ & $150 \pm 1$ & $118 \pm 1$ & $6 \pm 1$ & $74 \pm 1$ & $4 \pm 2$ & $<\mathrm{DL}$ \\
\hline \multirow[t]{2}{*}{$05 / 08$} & Inside "Eye" Tower & $<\mathrm{DL}$ & $<\mathrm{DL}$ & $85 \pm 14$ & $24 \pm 5$ & $120 \pm 1$ & $8 \pm 2$ & $<\overline{\mathrm{DL}}$ & $<\mathrm{DL}$ & $<\mathrm{DL}$ & $<\mathrm{DL}$ \\
\hline & Outside & $138 \pm 7$ & $200 \pm 5$ & $151 \pm 10$ & $49 \pm 3$ & $270 \pm 1$ & $358 \pm 1$ & $21 \pm 1$ & $187 \pm 3$ & $7 \pm 4$ & $22 \pm 1$ \\
\hline \multirow[t]{2}{*}{ 06/08 } & Inside "Eye" Tower & $<\mathrm{DL}$ & $<\mathrm{DL}$ & $13 \pm 5$ & $10 \pm 2$ & $12 \pm 1$ & $8 \pm 1$ & $<\mathrm{DL}$ & $<\mathrm{DL}$ & $<\mathrm{DL}$ & $<\mathrm{DL}$ \\
\hline & Outside & $28 \pm 5$ & $48 \pm 4$ & $38 \pm 7$ & $16 \pm 2$ & $59 \pm 1$ & $89 \pm 1$ & $5 \pm 1$ & $47 \pm 2$ & $<\mathrm{DL}$ & $<\mathrm{DL}$ \\
\hline
\end{tabular}

agent in the silicate glass. In the leached layer on the glass surface Fe and predominantly Mn can lead to a brown discoloring of the surface layer due to an oxidation process of $\mathrm{Mn}$ (II) oxide to manganese dioxide (Schreiner, 1991).

The indoor/outdoor ratio $(\mathrm{I} / \mathrm{O})$ points out the lower amount of bulk particles inside of the Eye Tower, suggesting that the HVAC system is able to retain a significant part of the total PM (Van Grieken et al., 2000; Godoi et al., 2008; Camuffo et al., 2001; Gysels et al., 2004).

\subsection{Single particle analysis}

The single particle analysis (SPA) results from MON, presented in Table 3, show the relative abundance of individual particle types obtained inside and outside of the museum. For all samples collected inside and outside, 6 major types of aerosol particles based on their chemical compositions are significantly encountered: biogenic, calcium carbonate, calcium sulfate, soil dust, organic and soot.

Calcium sulfate particles can be released by the plastered wall indoors and others may be introduced from the outdoor urban atmosphere. In Table 3, overall relative abundances of those particle types are shown for the 4 samples. The overall relative abundance is calculated by dividing the encountered number of the specific type of particles by the total number of analyzed particles for each sample. The results obtained for SPA show the abundance of various particle clusters.

Two types of clusters that contain Ca species were found: calcium carbonate $\left(\mathrm{CaCO}_{3}\right)$ and calcium sulfate $\left(\mathrm{CaSO}_{4}\right)$. There are some theoretical possibilities for the origin of $\mathrm{CaSO}_{4}$, such as crustal sources and the atmospheric conversion of $\mathrm{CaCO}_{3}$ species reacting with $\mathrm{SO}_{2}$. Gas-particle adsorption to produce $\mathrm{CaSO}_{4}$ is known to occur under conditions of high relative humidity (Camuffo et al., 2001), especially in a polluted urban area. An additional process that can take place

Table 3

Relative abundance of the obtained particle types (combined groups) observed in the eight samples.

\begin{tabular}{|c|c|c|c|c|}
\hline \multirow[t]{2}{*}{ Cluster \% } & \multicolumn{2}{|l|}{ Inside } & \multicolumn{2}{|l|}{ Outside } \\
\hline & $0.2-2.0(\mu \mathrm{m})$ & $2.0-8.0(\mu \mathrm{m})$ & $0.2-2.0(\mu \mathrm{m})$ & $2.0-8.0(\mu \mathrm{m})$ \\
\hline Biogenic & 18 & 13 & 4 & 17 \\
\hline Organic & 17 & 13 & 10 & 15 \\
\hline Soil dust & 16 & 15 & 50 & 21 \\
\hline Soot & 13 & 0 & 15 & 27 \\
\hline S-rich & 6 & 11 & 6 & 13 \\
\hline S-Cl-rich & 2 & 8 & 0 & 0 \\
\hline Cl-rich & 0 & 5 & 0 & 0 \\
\hline $\mathrm{CaSO}_{4}$ & 17 & 23 & 0 & 0 \\
\hline $\mathrm{CaCO}_{3}$ & 8 & 10 & 14 & 9 \\
\hline $\mathrm{FeO}$ & 1 & 1 & 0 & 1 \\
\hline Mixed & 0 & 2 & 0 & 0 \\
\hline
\end{tabular}

is the absorption of $\mathrm{SO}_{2}$ by the plastered walls. Both particles may originate from the degradation of museum plaster walls. $\mathrm{CaSO}_{4}$ has also a damaging potential for the artwork, causing the darkening of the surfaces when it adsorbs e.g. soot. The deterioration process of the walls and consequent re-suspension of the $\mathrm{CaSO}_{4}$ produced can also be an internal source of gypsum, although the walls of the MON are in very good condition.

Particles that are produced by living organisms are called biogenic aerosols such as pollens, fungi spores, bacteria and viruses. However, vegetation fires can also be considered another source of biogenic aerosols. The high amount of biogenic particles present inside the museum may be associated with large green area that surrounds the museum.

The indoor to outdoor concentration ratios revealed a significant enrichment of organic particles at most of the indoor sample locations, especially in the fine fraction, indicating an accumulation process due to chemical reactions taking place in the micro-environment and/or the infiltration due to the unsealed condition of the museum. This is in agreement with previous research, where the pollutant composition in museums using HVAC was found to be mainly due to organic carbonaceous particles and soil dust (Godoi et al., 2008). Organic particles with a high S-content were observed abundantly inside of the museum. These small size fraction particles can stay in the air for a longer time than the coarse fraction particles and at high humidity, potential S-incorporation from the air may result. These particles are of particular importance with regard to conservation and preservation of artifacts (Brimblecombe et al., 1999; Camuffo et al., 1999). For instance, the oxidation of S-rich particles to sulfuric acid can cause discolouration of paintings.

Table 4

Results obtained in the first sampling week (07/30 to 08/06/2007) at Point 1 , in the "Eye" Tower.

\begin{tabular}{|c|c|c|c|c|}
\hline Sampling site & Day & $\begin{array}{l}\text { Mean } \\
\left(\mathrm{ng} \mathrm{m}^{-3}\right)\end{array}$ & $\begin{array}{l}\text { Maximum } \\
\left(\mathrm{ng} \mathrm{m}^{-3}\right)\end{array}$ & $\begin{array}{l}\text { Minimum } \\
\left(\mathrm{ng} \mathrm{m}^{-3}\right)\end{array}$ \\
\hline \multirow[t]{11}{*}{ Point 1 ("Eye" Tower) } & $07 / 30$ & 2900 & 23150 & 102 \\
\hline & $07 / 31$ & 9400 & 25120 & 7 \\
\hline & $08 / 01$ & 5900 & 30340 & 8 \\
\hline & $08 / 02$ & 7700 & 78610 & 17 \\
\hline & $08 / 03$ & 8300 & 24880 & 286 \\
\hline & 08/04 (morning) & 6000 & 25110 & 3 \\
\hline & 08/04 (afternoon) & 7100 & 27740 & 31 \\
\hline & 08/05 (morning) & 5800 & 42560 & 28 \\
\hline & 08/05 (afternoon) & 4700 & 22008 & 35 \\
\hline & 08/06 & 6500 & 57800 & 185 \\
\hline & \multicolumn{4}{|c|}{ Total average concentration: 6580} \\
\hline \multirow[t]{4}{*}{ Point 13 (main building) } & $08 / 23$ & 9000 & 36950 & 87 \\
\hline & $08 / 24$ & 8900 & 29260 & 1 \\
\hline & $08 / 25$ & 12000 & 44780 & 169 \\
\hline & \multicolumn{4}{|c|}{ Total average concentration: 9960} \\
\hline Outside & $08 / 27$ & 16400 & 48740 & 437 \\
\hline
\end{tabular}


Table 5

Results obtained for gases in the first sampling week (07/30 to 08/06/2007).

\begin{tabular}{lclc}
\hline Sample location & $\mathrm{NO}_{2} \mu \mathrm{g} \mathrm{m}^{-3}$ & $\mathrm{SO}_{2} \mu \mathrm{g} \mathrm{m}^{-3}$ & $\mathrm{O}_{3} \mu \mathrm{g} \mathrm{m}^{-3}$ \\
\hline Point 1 & 6.8 & 0.2 & 1.6 \\
Point 2 & 6.7 & 0.2 & 0.8 \\
Point 3 & 11 & 1.3 & 4.3 \\
Point 4 (outdoor) & 24 & 1.9 & 21 \\
\hline
\end{tabular}

\subsection{Black carbon}

In the field of cultural heritage, BC mainly causes soiling and blackening of surfaces, causing undesirable esthetic effects as black crust formation and material decohesion (Brimblecombe, 1990; Camuffo, 1998). The results obtained for BC at the MON are displayed in Table 4.

It is clear from Table 4 that the concentration of $\mathrm{BC}$ is significantly higher outside than inside. It is also interesting to notice that the two lowest average BC concentrations occurred in periods of low vehicular traffic in the museum area, being the concentration of $4700 \mathrm{ng} \mathrm{m}^{-3}$ registered on a Sunday afternoon (08/05/2007) and the concentration of $2900 \mathrm{ng} \mathrm{m}^{-3}$ on a Monday (07/30/2007) on which the museum was closed. This confirms that the main source of BC to the atmosphere can be attributed to the vehicular traffic. Besides, when comparing the $\mathrm{BC}$ concentration obtained at Points 1 and 13, it can be seen that the main building presented higher average indoor concentration than the "Eye" building, which can be attributed to the fact that the main building presents more points of natural exchange of air, allowing a greater rate of transport of $\mathrm{BC}$ to the building interior.

The indoor concentration values obtained by the present study are similar to those of studies carried out in American museums by Ligocki et al. (1993) and Nazaroff et al. (1993). These museums do not present specific filtering for PM, similarly to the MON. However, museums which use the filters acting on BC (Norton Simons Museum and Scott Gallery) present much lower indoor concentrations of BC (Nazaroff et al., 1993; Ligocki et al., 1993). A positive result is the relative low amount of black carbon (soot) particles inside of the MON. The deposit of these types of particles on works of art is recognized as being the main reason for the soiling and chemical degradation of collections.

\section{4. $\mathrm{NO}_{2}, \mathrm{SO}_{2}$ and $\mathrm{O}_{3}$}

Table 5 displays the concentrations obtained for $\mathrm{NO}_{2}, \mathrm{SO}_{2}$ and $\mathrm{O}_{3}$ gases in the first sampling week.

One may notice that the concentration values of $\mathrm{NO}_{2}, \mathrm{SO}_{2}$ and $\mathrm{O}_{3}$ outside of the building (Point 4) are considerably higher than the ones obtained in the indoor environment. It was also observed an important concentration gradient between Points 1 and 2 with respect to Point 3. The $\mathrm{I} / \mathrm{O}$ ratio for these pollutants indicates that there are no significant sources placed indoors. The concentration of $\mathrm{NO}_{2}$ is usually high in an urban atmosphere, due to its emission by automobiles. Since MON is located close to streets of heavy vehicular traffic, it is expected to obtain higher concentration of $\mathrm{NO}_{2}$.

Usually, for naturally ventilated buildings, the indoor concentration values of $\mathrm{O}_{3}$ are approximately half the outdoor values (Shaver and Cass, 1983). At MON, however, the indoor concentration is much lower than that, which can be due to high rates of deposition of $\mathrm{O}_{3}$,

Table 6

Results obtained for HAc and HFor in the first sampling week (07/30 to 08/06/2007).

\begin{tabular}{lll}
\hline Sample location & $\mathrm{HAc} \mu \mathrm{g} \mathrm{m}^{-3}$ & HFor $\mu \mathrm{g} \mathrm{m}^{-3}$ \\
\hline Point 1 & 5.7 & 13 \\
Point 2 & 5.7 & 7.7 \\
Point 3 & 2.4 & 1.7 \\
Point 4 (outdoor) & 2.2 & 2.4 \\
\hline
\end{tabular}

Table 7

Results obtained for HAc and HFor in the second sampling week (08/20 to 08/27/2007).

\begin{tabular}{|c|c|c|}
\hline Sample Location & $\mathrm{HAc} \mu \mathrm{g} \mathrm{m}^{-3}$ & HFor $\mu \mathrm{g} \mathrm{m}^{-3}$ \\
\hline Point 5 & 2.8 & $<\mathrm{DL}^{\mathrm{a}}$ \\
\hline Point 6 & 2.7 & $<\mathrm{DL}$ \\
\hline Point 7 & 2.7 & $<\mathrm{DL}$ \\
\hline Point 8 & 3.4 & $<\mathrm{DL}$ \\
\hline Point 9 & 3.8 & $<\mathrm{DL}$ \\
\hline Point 10 & 2.4 & $<\mathrm{DL}$ \\
\hline Point 11 & 2.6 & $<\mathrm{DL}$ \\
\hline Point 12 & 2.6 & $<\mathrm{DL}$ \\
\hline
\end{tabular}

a $<$ DL: Under the detection limit $\left(0.2 \mu \mathrm{g} \mathrm{m}^{-3}\right)$.

Table 8

Results obtained for BETX in the first sampling week (07/30 to 08/06/2007).

\begin{tabular}{llllll}
\hline Sample location & $\begin{array}{l}\text { Benzene } \\
\mu \mathrm{g} \mathrm{m}^{-3}\end{array}$ & $\begin{array}{l}\text { Toluene } \\
\mu \mathrm{g} \mathrm{m}^{-3}\end{array}$ & $\begin{array}{l}\text { Ethyl benzene } \\
\mu \mathrm{g} \mathrm{m}^{-3}\end{array}$ & $\begin{array}{l}\mathrm{m}+\mathrm{p} \text { xylene } \\
\mu \mathrm{g} \mathrm{m}^{-3}\end{array}$ & $\begin{array}{l}\text { o-Xylene } \\
\mu \mathrm{g} \mathrm{m}^{-3}\end{array}$ \\
\hline Point 1 & $<\mathrm{DL}$ & 2.3 & 1 & $<\mathrm{DL}$ & 0.9 \\
Point 2 & $<\mathrm{DL}$ & $<\mathrm{DL}$ & 1.6 & $<\mathrm{DL}$ & 1.4 \\
Point 3 & 0.2 & 1.5 & 2.4 & $<\mathrm{DL}$ & 2.6 \\
Point 4 (outdoor) & 0.8 & $<\mathrm{DL}$ & $<\mathrm{DL}$ & $<\mathrm{DL}$ & $<\mathrm{DL}$ \\
\hline
\end{tabular}

mainly in the floor carpets (De Santis et al., 1992), or due to reactions with other pollutants in the indoor atmosphere of the museum.

The US National Bureau of Standards defined guidelines for atmospheric pollutants inside museums, in order to preserve the artworks exposed. The $\mathrm{SO}_{2}$ and the $\mathrm{O}_{3}$ pollutions detected in the MON are below the limits defined by the US National Bureau of Standards, but the $\mathrm{NO}_{2}$ concentration values are slightly higher. However, when considering the guidelines defined by the Museum Environment, $\mathrm{NO}_{2}$ concentration attends the defined limits (Blades et al., 2000).

The mean concentration values for $\mathrm{NO}_{2}$ and $\mathrm{SO}_{2}$ obtained in the present research are in general lower than the mean concentrations obtained in European museums (Camuffo et al., 1999, 2001; De Saints et al., 2003; Godoi et al., 2004). For $\mathrm{SO}_{2}$, this difference can be explained due to the fact that in Brazil there is much higher use of ethanol as automobile fuel, which emits no $\mathrm{SO}_{2}$, than diesel, which is largely used in Europe and still constitutes a (minor) source of $\mathrm{SO}_{2}$ to the urban atmosphere.

\subsection{HAc and HFor}

Tables 6 and 7 display the concentrations obtained for HAc and HFor in both sampling weeks.

For both pollutants, the indoor concentration values were in general higher than the outdoor values, indicating the presence of indoor sources of HAc and HFor. This pattern is most likely due to the presence of few plywood boards, which were used as a support for the art expositions in the sampling locations and are known as an important indoor source of both acids. The concentration of HAc and HFor inside the MON is very low compared with that inside the other

Table 9

Results obtained for BTEX in the second sampling week (08/20 to 08/27/2007).

\begin{tabular}{llclcl}
\hline Sample location & $\begin{array}{l}\text { Benzene } \\
\mu \mathrm{g} \mathrm{m} \mathrm{m}^{-3}\end{array}$ & $\begin{array}{c}\text { Toluene } \\
\mu \mathrm{g} \mathrm{m}^{-3}\end{array}$ & $\begin{array}{l}\text { Ethyl benzene } \\
\mu \mathrm{g} \mathrm{m}^{-3}\end{array}$ & $\begin{array}{l}\mathrm{m}+\mathrm{p} \text { xylene } \\
\mu \mathrm{g} \mathrm{m}^{-3}\end{array}$ & $\begin{array}{l}\text { o-Xylene } \\
\mu \mathrm{g} \mathrm{m}^{-3}\end{array}$ \\
\hline Point 5 & $<\mathrm{DL}$ & 2 & 13.6 & 8.1 & 20.4 \\
Point 6 & $<\mathrm{DL}$ & 2.6 & 19.2 & 12.4 & 29.5 \\
Point 7 & 1.2 & 5.5 & 11.3 & 12.3 & 29.4 \\
Point 8 & $<\mathrm{DL}$ & 2.5 & 11.7 & 8.3 & 20.9 \\
Point 9 & $<\mathrm{DL}$ & 0.7 & 11.2 & 7.9 & 20.1 \\
Point 10 & $<\mathrm{DL}$ & $<\mathrm{DL}$ & 8.4 & 5.3 & 14.4 \\
Point 11 & $<\mathrm{DL}$ & 2 & 15 & 16.3 & 37.8 \\
Point 12 & 0.6 & 1.1 & 17.4 & 17 & 39.3 \\
\hline
\end{tabular}




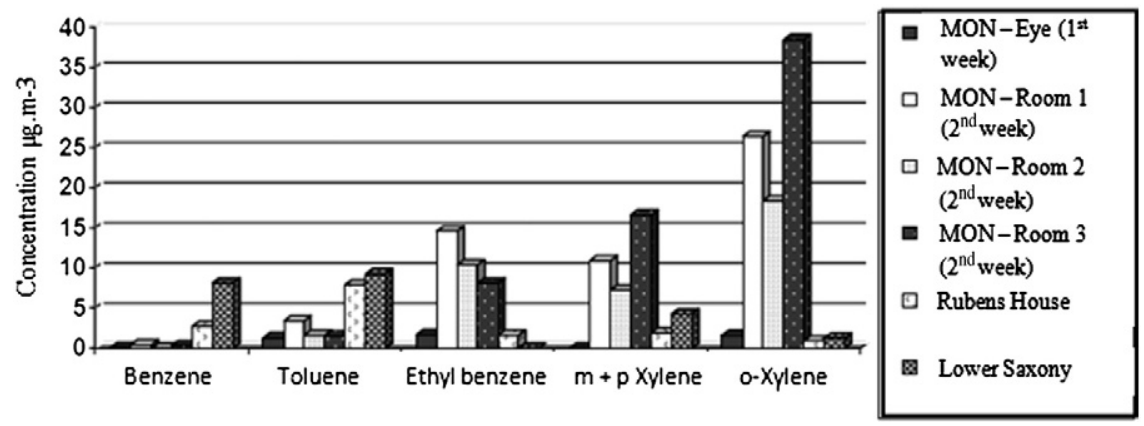

Fig. 2. Comparison between average BTEX concentrations obtained at the MON, the Rubens House and the Lower Saxony State Museums.

museums worldwide. For instance, in the galleries and in the outdoor air of Metropolitan Museum, high concentrations of organic acids were found, with average concentrations of $50 \mu \mathrm{g} \mathrm{m}^{-3}$ of acetate and $10 \mu \mathrm{g} \mathrm{m}^{-3}$ of formate (Kontozova-Deutsch et al., 2011b).

There are still no guidelines for these pollutants in museum indoor environments, but it is expected that concentrations below $10.5 \mu \mathrm{g} \mathrm{m}^{-3}$ are found (Blades et al., 2000). Even though the results in the present research are below this value, it is important to notice that the exposure of the museum's collections to HAc and HFor for a long period of time, even at low concentrations, may cause irreversible damage.

\subsection{BTEX}

Tables 8 and 9 display the concentrations obtained for BTEX in both sampling weeks.

When comparing both tables, it is clear that the BTEX concentration is lower in the "Eye" building than in the main building. This happened most likely because an exposition room at the main building, near the ones where the sampling was taking place, was being painted, and paints are known to represent one of the greatest sources of BTEX, since these substances are used as solvent in them.

It can be noticed that only 3 of the indoor locations indicated the presence of benzene, two of these are close to openings, where natural exchange of air takes place (Points 3 and 7) and the other one is close to the room which was being painted (Point 12). Thus, it suggests that the most important sources of benzene are outdoors (exhaust of automobiles), and this pollutant is being carried to the indoor environment. The other pollutants were not found outdoors, but were found indoors, indicating that they have emission sources placed in the indoor environment. At the time of the sampling, there were potential sources of these pollutants placed in the "Eye" building, such as wood structures and glass recently painted, while in the main building there was a room being painted, as already mentioned.

Compared to MON, the Rubens House Museum, Belgium (Godoi et al., 2008) and the Lower Saxony State Museum, Germany (Schieweck et al., 2005) presented higher average concentration of benzene and toluene, as shown in Fig. 2. However, when analyzing the average concentrations of ethyl benzene, $\mathrm{m}+\mathrm{p}$ xylene and o-xylene, the Brazilian museum showed higher levels of pollution, mainly at the main building. Again, this result is most likely due to the painting process that was taking place at the room near the sampling locations.

It is known that BTEX are potentially corrosive. Besides, benzene and toluene act on inorganic pigments (Agelakopoulou et al., 2007) and ethyl benzene and xylenes, being solvents, can also act on pigments used in paints, altering the coloration of the artworks.

\section{Conclusions}

When comparing the air quality of the MON, characterized in the present study, to the air quality of other international museums, one can conclude that the MON has a satisfactory air quality, which may be favoring the conservation of its art collection.

$\mathrm{SO}_{2}$ and $\mathrm{O}_{3}$ presented low indoor concentrations, below the limits defined by both the US National Bureau of Standards and the Museum Environment (Thomson, 1986), while $\mathrm{NO}_{2}$ attends the guidelines only for the last one.

Acetic acid was detected at low concentrations in both studied buildings, while formic acid was detected only at the "Eye" building, also at low concentrations. Regarding BTEX concentrations, the values obtained at the main building were significantly higher than the ones obtained at the "Eye" building. This trend was due to the painting of an exposition room close to the sampling sites at the main building, which was happening at the time of the sampling period.

The elemental analysis of total PM showed values which, when compared to other studies, were low, especially for the most damaging elements to the artworks, such as S and Fe. The element found at the highest concentrations was $\mathrm{K}$, which presents no damage potential to the artworks.

In the SPA, a relatively high abundance of biogenic and organic particles was found. The percentage of the most harmful particles to the artwork was low in comparison with the findings of other studies.

The $\mathrm{BC}$ concentrations were directly related to the intensity of the vehicle traffic in the surrounding area. The values obtained in the present study are similar to the values reported by other studies.

From the point of view of conservation, it became clear that the artworks are not directly threatened by particulate pollution. Still, the situation could be improved by employing filters with higher collection efficiency in the HVAC system, especially for small particles.

\section{Acknowledgment}

Special thanks to Mrs. Suelly Deschermayer and all the staff of the Oscar Niemeyer Museum for their sincere interest in this work and their eager assistance during the measurement campaigns.

\section{References}

Agelakopoulou T, Bassiotis I, Metaxa E, Roubain-kalantzopoulou F. Benzene and toluene influence with or without nitrogen dioxide on inorganic pigments of works of art part II. Atmos Environ 2007;41:1009-18.

Avigo D, Godoi AFL, Janissek PR, Makarowska J, Krata A, Vermaak SP, et al. Particulate matter analysis at elementary schools in Curitiba, Brazil. Anal Bioanal Chem 2008;391:1459-68.

Bencs L, Spolnik Z, Limpens-Neilen D, Schellen HL, Jütte BAHG, Van Grieken R. Impact of hot-air blow and low-radiant pew heating systems on the distribution and transport of gaseous air pollutants in the mountain church of Rocca Pietore from artwork conservation points of view. J Cult Herit 2007;8:264-71.

Blades NW, Bordass W, Oreszczyn T, Cassar M. Guidelines on pollution control in museum buildings. London: Museum Practice; 2000.

Bratasz L, Kozlowski R, Camuffo D, Pagan E. Impact of indoor heating on painted wood monitoring the altarpiece in the Church of Santa Maria Maddalena in Rocca Pietore, Italy. Stud Conserv 2007;52(3):199-210.

Brimblecombe P. The composition of museum air. Atmos Environ 1990;24B:1-8

Brimblecombe P, Blades N, Camuffo D, Sturaro G, Valentino A, Gysels K, et al. The indoor environment of a modern museum building. The Sainsbury center for visual arts, Norwich, UK. Indoor air; 1999. p. 146-64. 
Campos VP, Cruz LPS, Godoi RHM, Godoi AFL, Tavares TM. Development and validation of passive samplers for atmospheric monitoring of $\mathrm{SO}_{2}, \mathrm{NO}_{2}, \mathrm{O}_{3}$ and $\mathrm{H}_{2} \mathrm{~S}$ in tropical areas. Microchem J 2010;96:132-8.

Camuffo D. Microclimate for cultural heritage. Amsterdam: Elsevier; 1998.

Camuffo D, Brimblecombe P, Van Grieken R, Busse H-J, Sturaro G, Valentino A, et al. Indoor air quality at the Correr Museum, Venice, Italy. Sci Total Environ 1999;236: 135-52.

Camuffo D, Van Grieken R, Busse HJ, Sturaro G, Valentino A, Bernardi A, et al. Environmental monitoring in four European museums. Atmos Environ 2001;35:127-40.

Cappitelli F, Fermo P, Vecchi R, Piazzalunga A, Valli G, Zanardini E, et al. Chemicalphysical and microbiological measurements for indoor air quality assessment at the Ca'Granda Historical Archive, Milan (Italy). Water Air Soil Pollut 2009;201: 109-20.

Cavicchioli A, de Souza ROC, Reis GR, Fornaro A. Indoor air quality in heavily polluted cities: ozone and nitrogen dioxide contamination in the indoor atmosphere of two museums of São Paulo, Brazil. Indoor air quality in heritage and historic environments; 2012. p. 17-20.

Cocheo V, Boaretto C, Sacco P. High uptake rate radial diffusive sampler suitable for both solvent and thermal desorption. Am Ind Hyg Assoc J 1996;57:897-904.

Costa V. Museum's air quality in a tropical climate: evaluation by using metallic coupons. 5th meeting of the Indoor Air Pollution Working Group University of East Anglia, School of Environmental Sciences, Norwich; 2003.

De Saints F, Vazzana C, Menichelli S, Allegrini I. The Measurement of atmospheric pollutants by passive sampling at the Uffizi Gallery, Florence. Ann Chim 2003;93:45-52.

De Santis F, Di Palo V, Allegrini I. Determination of some atmospheric pollutants inside a museum: relationship with the concentration outside. Sci Total Environ 1992;127(3): 211-23.

Druzik CM, Grosjean D, Van Neste A, Parmar SS. Sampling of atmospheric carbonyls with small DNPH-coated C18 cartridges and liquid chromatography analysis with diode array detection. Int J Environ Anal Chem 1990;38(4):495-512.

Environmental Institute of Paraná (Instituto Ambiental do Paraná - IAP). Available in: http://www.iap.pr.gov.br 2008. [Accessed: 26 Feb 2008].

Godoi RHM, Godoi AFL, Worobiec A, Andrade SJ, Hoog J, Santiago-Silva MR, et al. Characterization of sugar cane combustion particles in the Araraquara Region, Southeast Brazil. Microchim Acta 2004;145:53-6.

Godoi RHM, Kontozova V, Van Grieken R. The shielding effect of the protective glazing of historical stained glass windows from an atmospheric chemistry perspective: case study Sainte Chapelle, Paris. Atmos Environ 2006a;40:1255-65.

Godoi RHM, Potgieter-Vermaak S, De Hoog J, Kaegi R, Van Grieken R. Substrate selection for optimum qualitative and quantitative single atmospheric particles analysis using nano-manipulation, sequential thin-window electron probe X-ray microanalysis and micro-Raman spectrometry. Spectrochim Acta B 2006b;61:375-88.

Godoi RHM, Potgieter-Vermaak S, Godoi AFL, Stranger M, Van Grieken R. Assessment of aerosol particles within the Rubens House Museum in Antwerp, Belgium. X-Ray Spectrom 2008;37(4):298-303.

Godoi AFL, Sawada EY, Marchi MRR, Van Grieken R, Godoi RHM. Determination of BTEX by GC-MS in air of offset printing plants: comparison between conventional and ecological inks 2009. Water Air Soil Pollut 2009;9:163-9.
Grosjean D, Miguel AH, Tavares TM. Urban air pollution in Brazil: acetaldehyde and other carbonyls. Atmos Environ 1990;24B:101-6.

Gysels K, Delalieux F, Deutsch F, Van Greken R, Camuffo D, Bernardi A, et al. Indoor environment and conservation in the Royal Museum of Fine Arts, Antwerp, Belgium J Cult Herit 2004;5:221-30.

Hansen DA, Schnell RC. The aethalometer. Magge Scientific Company; 1991.

Hildemann LM, Mazurek MA, Cass GR, Simoneit BRT. Quantitative characterization of urban sources of organic aerosol by high-resolution gas chromatography. Environ Sci Technol 1991;25:1311-25.

Ionescu A, Lefevre R-A, Brimblecombe P, Grossi CM. Long-term damage to glass in Paris in a changing environment. Sci Total Environ 2012;431:151-6.

IPCC. Report of working group I of the intergovernmental panel on climate change, summary for policymakers; 2001.

Kontozova-Deutsch V, Deutsch F, Godoi RHM, Spolnik Z, Wei W, Van Grieken R. Application of EPMA and XRF for the investigation of particulate pollutants in the field of cultural heritage. Microchim Acta 2008;161:465-9.

Kontozova-Deutsch V, Deutsch F, Godoi RHM, Van Grieken R, De Wael K. Urban air pollutants and their micro effects on medieval stained glass windows. Microchem J 2011a;99(2):508-13.

Kontozova-Deutsch V, Deutsch F, Bencs L, Krata A, Van Grieken R, De Wael K. Optimization of the ion chromatographic quantification of airborne fluoride, acetate and formate in the Metropolitan Museum of Art, New York. Talanta 2011b;86:372-6.

Lankester P, Brimblecombe P. The impact of future climate on historic interiors. Sci Total Environ 2012;417-418:248-54.

Lefevre M. La “Maladie Verte” de Lascaux. Stud Conserv 1974;19(3):126-56.

Ligocki MP, Salmon LG, Fall T, Jones MC, Nazaroff WW, Cass GR. Characteristics of airborne particles inside southern California museums. Atmos Environ 1993;27A: 697-711.

Nazaroff WW, Ligocki MP, Salmon LG, Cass GR, Fall T, Jones MC, et al. Airborne particles in museums. The Getty Conservation Institute; 1993.

Schieweck A, Lohrengel B, Siwinski N, Genning C, Salthammer T. Organic and inorganic pollutants in storage rooms of the Lower Saxony State Museum Hanover, Germany. Atmos Environ 2005;39:6098-108.

Schreiner M. Glass of the past-the degradation and deterioration of medieval glass artifacts. Mikrochim Acta 1991;2:255-64.

Shaver CL, Cass GR. Ozone and the deterioration of works of art. Environ Sci Technol 1983;17:748-52.

Stranger M, Potgieter-Vermaak S, Sacco P, Quaglio F, Pagani D, Cocheo C, et al. Analysis of indoor gaseous formic and acetic acid, using radial diffusive samplers. Environ Monit Assess 2009;149:411-7.

Thomson G. The museum environment. 2nd ed. London: Butterworths; 1986.

Van Grieken R, Gysels K, Hoornaert S, Joos P, Osan J, Szaloki I, et al. Characterization of individual aerosol particles for atmospheric and cultural heritage studies in environmental challenges. Water Air Soil Pollut 2000;123(1-4):215-28.

Wolf ME, Hidy GM. Aerosols and climate: anthropogenic emissions and trends for 50 years. J Geophys Res 1997;102(10):11-113.

Yi C, Davis KJ, Bakwin PS, Berger BW. Long-term observations of the dynamics of the continental planetary boundary layer. J Atmos Sci 2001;58:1288-99. 